\title{
Soil Microbiology in Agricultural Research in Relation to Ancient Knowledge
}

\author{
Raúl Hernando Posada* \\ Universidad de Caldas, USA
}

Submission: April 22, 2017; Published: April 28, 2017

"Corresponding author: Raúl Hernando Posada, Universidad de Caldas, Facultad de ciencias exactas y naturales, Programa de Biología, Calle 65 \# 26-10, Manizales-Colombia, USA, Tel: +57 3002031640; Email: raulposada@hotmail.com

Abstract

Actually the advances in massive communication media and social networks have allowed us to know the preferences in agricultural research worldwide, which are specially focused in areas of genetics, plant pathology, tillage techniques and agro-ecology. The main effort is for food products with global distribution leaving beside native or forgotten species and varieties. Soil microbiology is more generalist in microorganisms and plant species that previously mentioned areas, giving attention to beneficial interactions. Application of soil microbiology along with the ancient knowledge in forgotten crops can help to promote their production, diffusion and conserve the genetic pool.

Keywords: Ancient knowledge; Soil microbiology; Forgotten crops

\section{Introduction}

Research gaps have been covered thanks to the advances in technology and scientific knowledge. Nowadays, many assays have been conducted in the quest to create applied technologies in agriculture, trying to a) improve life quality, b) supply the world next year's food requirements, c) recovering degraded soils and, d) obtain products and competitive advantages under the global climatic change [1,2].

There searches are diverse and comprehensive ranging from simple crop selection to the genetic management [3]. They also include genes selection to create resistance against pests, the productivity improvement to produce high quality crops and, inclusion of foreign genes in plants, all of them forecasting of supplement the human being nutrition $[4,5]$. These researches include the selection of a high variety of microorganisms with beneficial effects on plants, such as their nutrition and surviving in adverse conditions [6,7].

Unfortunately, many of these agricultural investigations are performed mainly over widely distributed plant species and varieties that are the source of food for the majority of word population [7-9]. These crops have a huge area on earth surface for their production $[1,2,10]$, leaving beside and forgetting a high amount of native varieties or plant species with nutritional or medicinal potential [11-13].
Crops characterized by their low productivity, low demand, reduced size, long harvesting time, or restricted distribution because of specific local growing conditions, but with high nutritional value or with desired medicinal properties are scarcely investigated. Species such as quinua (Chenopodium quinoa), ibia (Oxalis tuberosa), cubio (Tropaeolum tuberosum), mangostine (Garciniamangostana), yacon (Smallanthus sonchifolius), nispero (Eriobotrya japonica), pomarrosa (Syzygium jambos), pupunha (Bactris gasipaes), taperebá (Malpighia emarginata), buriti (Mauritia flexuosa), Nispola (Mespilus germanica), salac (Salacca zalacca), durian (Durio zibethinus), rambutan (Nephelium lappaceum), and other plant species are poorly studied $[11,12]$. Along with previous species, forgotten varieties of crops such as beans (Phaseolus vulgaris), and corn (Zea mays), are limited to local or native are as for their use and management [13].

Among agricultural biotechnology, the soil microbiology has a contrasting perspective because it has not a strict specificity with plant species. In the latter area, the biotechnological advances usually are widely used. For example, fungi and bacteria with phosphate solubilizing capacities are investigated in terms of solubilizing capacity of different phosphate sources, the effects of environment in their performance, their association with different plant species, their nutritional benefits in association with different crops in different soil pHs or with different carbon 
sources [14-16]. Furthermore, the symbiotic nitrogen-fixing bacteria have been studied in terms of their plant association and geographical distribution. Al together with nitrogen free fixing bacteria, they have been evaluated in their nitrogen fixing capacity, their behaviour in different conditions and habitats, their association with different crops, and in search and selection of the most effective methods and culture medium for propagation, even in the search of genes that determines their functioning [17-19].

Finally the Arbuscular Mycorrhizal Fungi (AMF) is characterized because of the low specificity in their association with plants [20]. In these fungi, different species of 270 recognized are associated with the $90 \%$ of plant species. Different fungal species can be associated with the same plant species. In the root association, fungal species can change with phenological plant development and environmental conditions [21]. The fungal genera Glomus and Acaulospora have cosmopolitan distribution and can be found in different elevations in the five continents [22-24]. The studies in these microorganisms are focused in their association with different plant species, their changes in association, their characterization in different natural and cultivated systems, their capacities to decontaminate the soils and promote the plant growth and productivity [25-28].

Several studies of associative effects of microorganisms that promote plant growth are realized in microcosms conditions. Under these conditions, the results anticipate or replicate the association behaviour in field conditions [29,30]. This kind of assays are usually performed with pure strains as with mixes of microorganisms, sometimes the plants are exposed to microorganism similar or not to found in soils where extracted. In other cases, the environmental conditions are variable, from natural condition to stressing environments [31,32]; the results can be contradictory and in many occasions contrast with laboratory assays.

\section{Conclusion}

For the agricultural development, the perspectives of use of beneficial soil microorganisms constitute an imminent potential in the development and sustainability of conventional and traditional agriculture. The rescue of lost or hidden agriculture knowledge and traditions and crop management, that rest in memory of ancient people, behind the modern knowledge, deserve a high potential that needs to be exploited [12,33]. The fusion of soil biotechnology, ancient knowledge and modern research in forgotten crops is needed to promote their diffusion and conservation of the genetic pool. We must begin right now, taking advantage of the low specificity of soil associations and perhaps we already started without knowing it.

\section{References}

1. FAO (2013) Statistical year book 2013. ( $1^{\text {st }}$ edn), World food and agricultura, Rome, Italy.
2. Fischer T, Byerlee D, Edmeades G (2014) Crop yields and global food security. In: Fischer T, Byerlee D, Edmeades G (Eds.), Will yield increase continue to feed the world? ( $1^{\text {st }}$ edn $)$, ACIAR, Canberra, Australia, pp. $1-660$.

3. Netherland Study Centre for Technology Trends (2016) The future of technology in agriculture. In: de Wilde S (Ed.), The Hague, Netherlands, pp. 1-118.

4. Herdt RW (2006) Biotechnology in agriculture. Annu Rev Environ Resour 31: 265-295.

5. Teutonico RA (2009) Agricultural biotechnology risk analysis research in the federal goverment. Washington, USA.

6. Halos SC (2000) Agricultural biotechnology research and development in the Philippines: The Need for a Strategic Approach (2000-17). Diliman, Quezon, Philippines, pp. 1-57.

7. Huffman W (2009) Technology and Innovation in World Agriculture: Prospects for 2010-2019.

8. Leff B, Ramankutty N, Foley JA (2004) Geographic distribution of major crops across the world. Global Biogeo Cycles 18(1): 27.

9. Macauley H (2015) Cereal Crops: Rice, Maize, Millet, Sorghum, Wheat (Feeding Africa). Dahar, Senegal, West Africa.

10. Vitali I (2011) Soya and the Cerrado: Brazil's forgotten jewel. UK, p. 1-32.

11. NRC (2008) Lostcrops of Africa. Vol III - Fruits. The National Academies Press, Washington, USA.

12. Jusoh S (2009) Developing biotechnology innovations through traditional knowledge (Research papers No. 23). Geneva, Switzerland.

13. Nabhan CP (2010) Renewing America's food traditions. Forgotten fruits, Manual and Manifesto, Renewing America's Food Traditions (RAFT) Alliance.

14. Reddy SM, Kumar S, Babita K, Reddy MS (2002) Biosolubilization of poorly soluble rock phosphates by Aspergillus tubingensis and Aspergillus niger. Biores Tech 84(2): 187-189.

15. Vassilev N, Fenice M, Federici F (1996) Rock phosphate solubilization with gluconicacid produced by immobilized Penicillium variabile P16. Biotech Techniques 10(8): 585-588.

16. Rinu K, Pandey A (2010) Temperature-dependent phosphate solubilization by cold- and $\mathrm{pH}$-tolerant species of Aspergillus isolated from Himalayan soil. Mycoscience 51(4): 263-271.

17. Jimenez DJ, Montaña JS, Martinez MM (2011) Characterization of free nitrogen fixing bacteria of thegenus Azotobacter in organic vegetablegrown colombian soil. Brazilian J Microb 42(3): 846-858.

18. Gupta G, Panwar J, Akhtar M, Jha P (2012) Endophytic Nitrogen-Fixing Bacteria as Biofertilizer. In: Licht fouse E (Ed.), Sustainable Agriculture Reviews. ( $1^{\text {st }}$ edn), Springer Science+Business Media Dordrecht, Netherlands, pp. 183-221.

19. Shridhar BS (2012) Review: Nitrogen fixing microorganisms. Int ] Microb Res 3(1): 46-52.

20. Brachmann A, Parniske M (2006) The most wide spread simbiosis on Earth. PLoS Biol 4(7): 239-240.

21. Smith S, Read DJ (2008) Mycorrhizal Symbiosis Edition. ( $3^{\text {rd }}$ edn), Elsevier Inc, Netherlands.

22. Brundrett MC, Ashwath N, Jasper DA (1996) Mycorrhizas in the Kakadu region of tropical Australia. Plant Soil 184(1): 159-171.

23. Stürmer SL, Siqueira JO (2011) Species richness and sporea bundance of arbuscular mycorrhizal fungi across distinct land uses in Western Brazilian Amazon. Mycorrhiza 21(4): 255-267. 
24. Al-Yahya'ei MN, Oehl F, Vallino M, Lumini E, Redecker D, et al. (2011) Unique arbuscular mycorrhizal fungal communities un covered in date palm plantations and surrounding deserthabitats of Southern Arabia Mycorrhiza 21(3): 195-209.

25. Albuquerque da Silva M, Cavalcante TUM, Barbosa da Silva FS, Gomes Soares SA, Costa Maia L (2004) Crescimento de mudas de maracujazeiro-coce (Passifloraalata Curtis) associadas a fungos micorrízicosar busculares (Glomeromycota). Acta Bot Bras 18(4): 981 985.

26. ShardaKhade W, Rodrígues BF (2009) Studies on arbuscular mycorrhisation of papaya. African Crop Sci J 17(3): 155-165.

27. Yano-Melo AM, Saggin OJ, Maia CL (2003) Tolerance of mycorrhized banana (Musasp. cv. Pacovan) plantletstosaline stress. Agric Ecosyst Environ 95(1): 343-348.

28. Anzanello R, Dutra de Souza PV, Casamali B (2011) Fungos micorrízicosar busculares (FMA) em porta-enxertos micropropagados de videira. Bragantia Campinas 70(2): 409-415.
29. Draggan S (1976) The role of microcosms in ecological research. Int J Environ Studies 10(1): 1-2.

30. Kampichler C, Bruckner A, Kandeler E (2001) Use of enclosed model ecosystems in soil ecology: a bias towards laboratory research. Soil Biol Biochem 33: 269-275.

31. Kinkel LL, Wilson M, Lindow SE (1996) Utility of microcosm studies for predicting phylloplane bacterium population sizes in the field. Appl Env Microb 62(9): 3413-3423.

32. Khan MS, Zadir A (2007) Synergistic effects of the inoculation with plant growth-promoting Rhizobacteria and an Arbuscular Mycorrhizal Fungus on the performance of wheat. Turkish J Agric Forestry 31(6): 355-362.

33. Singh R, Sureja AK (2008) Indigenous knowledge and sustain able agricultural resources management under rainfed agro-ecosystem. Indian J Trad Knowledge 7(4): 642-654.

\section{Your next submission with Juniper Publishers will reach you the below assets}

- Quality Editorial service

- Swift Peer Review

- Reprints availability

- E-prints Service

- Manuscript Podcast for convenient understanding

- Global attainment for your research

- Manuscript accessibility in different formats

( Pdf, E-pub, Full Text, Audio)

- Unceasing customer service

Track the below URL for one-step submission https://juniperpublishers.com/online-submission.php 